\title{
Comparison of Two Techniques for the Detection of Environmental Fungi in a University Campus
}

\author{
Luz Dary Caicedo Bejarano ${ }^{1 *}$, Cristhian Delgado Ñañez ${ }^{1}$, \\ Mauricio Ramírez-Castrillón ${ }^{1}$, Álvaro León Rúa Giraldo ${ }^{2}$, Mónica Chavez Vivas ${ }^{3,4}$ \\ ${ }^{1}$ Facultad de Ciencias Básicas, Universidad Santiago de Cali, Calle 5 \# 62-00, Santiago de Cali. Colombia \\ ${ }^{2}$ Escuela de Microbiología, Universidad de Antioquía, Carrera. 51d \#62-29, Medellín, Colombia \\ ${ }^{3}$ Facultad de Salud, Universidad Santiago de Cali, Calle 5 \# 62-00, Santiago de Cali. Colombia \\ ${ }^{4}$ Facultad de Ciencias de la Salud. Universidad Libre. Carrera 109 No. 22 -00 - Valle del Lili. Cali. Colombia
}

Received:11 July 2020

Accepted: 2 November 2020

\begin{abstract}
Fungal contamination in closed or open environments has been well reported. However, studies that address airborne spores trap methods are scarce. In this study, two techniques were evaluated to detect fungal spores in the environment of three buildings of campus of a university in the city of Cali, Colombia. The gravimetric method of spore trapping was compared with the volumetric method (Air Ideal 3P) using the Omeliansky formula to determine the spore abundance. Environmental sampling was performed quarterly for a period of 12 months using dichloran rose bengal chloramphenicol agar. A total of $64,497 \mathrm{CFU} / \mathrm{m}^{3}$ were counted, of which $34,930 \mathrm{CFU} / \mathrm{m}^{3}$ were isolated using the volumetric method and 29,567 $\mathrm{CFU} / \mathrm{m}^{3}$ using the gravimetric method. No significant statistical differences were observed between the two techniques $(\mathrm{P}=0.0739$ ). The predominant genera obtained with both methods were Cladosporium, Penicillium, Aspergillus, and Fusarium, which suggests that although the gravimetric method is not as efficient as the volumetric method, it is reliable in estimating environmental fungal contamination.
\end{abstract}

Keywords: fungal spores, air sampling, volumetric, gravimetric, Omeliansky formula

\section{Introduction}

The air in indoor environments has a high load of biological particles comprising fungi, bacteria, viruses, and mites. Other airborne particles include pollen, dust, molecules of organic and inorganic origin,

*e-mail: ludcaice@usc.edu.co

toxins, and allergens. Owing to their small size, these particles are classified as bioaerosols and use air as a means of transport and propagation, thus reaching people who breathe an average of $14 \mathrm{~m}^{3}$ of air per day [1]. The concentration of these particles and other gases determines the air quality of a given place [2-6].

Fungi are eukaryotic, heterotrophic, non-chlorophyll, aerobic and/or facultative anaerobic, or macro or microscopic organisms. They can be saprophytes or 
parasites and obtain their food through absorptive nutrition. They reproduce by asexual and sexual spores necessary for their dispersal [7, 8]. Fungi are ubiquitous and are considered one of the main group of organisms present in both indoor and outdoor environments [9]. Fungi abundance depends on various environmental and topographic factors, such as nutrients, wind, temperature, relative humidity, time of day, geographic location, rainfall, light, human activity, disposal of biodegradable matter, adjacent vegetation, ventilation systems, and cleaning frequency. Conidia and spore size and shape [2, 10-14] favor the highest fungal concentration in temperate and tropical regions [15].

Studies on fungal contamination in various environments are numerous; however, studies that address airborne spores trap methods, such as the horizontal plate sedimentation method and volumetric method, are scarce [16]. Furthermore, studies differ among authors in terms of factors such as air volume, height of sample collection, and culture media used [3]. Several studies on environmental fungi have been performed in Colombia [17-23]. However, few have been conducted in the city of Santiago de Cali, and no studies have been performed for comparing different methods to capture spores in this city [22-25].

Urbanization, technological development, and various occupations have led humans to spend long periods of their time per day, up to $90 \%$, in closed spaces, such as offices, public and private institutions, hospitals, and homes. Therefore, contamination in these environments represents a public health concern [1, $26,27]$. In recent years, the interest in evaluating the biological quality of indoor air has increased owing to the fact that microorganisms contribute to the deterioration of materials and are dangerous agents that can cause systemic infections, mycotoxicosis, and respiratory allergies [2, 28], which can affect work performance and the quality of life of the general population [27, 29-32].

Air samplers used to assess microbiological quality can be expensive and are not available in all laboratories. Some small and medium-sized companies, health centers, educational centers, and the general population do not have the resources or the knowledge to use these samplers. Additionally, in some occasions, it is convenient to simultaneously perform several studies, which would require multiple sampling devices. Therefore, the gravimetric method continues to be widely used [33]. The Omeliansky formula allows to closely assess the data obtained using the impaction or volumetric techniques. The objective of this study was to assess two viable spore capture methods a passive method using horizontal plate sedimentation (gravimetric method) and an active volumetric method (Air Ideal ${ }^{\circ} 3 \mathrm{P} \circledast$ Treceability), under the same environmental conditions.

\section{Material and Methods}

\section{Study and Sampling Area}

This study was conducted in the campus Pampalinda at Universidad Santiago de Cali, located in the south of the city of Santiago de Cali (Valle del Cauca, Colombia). The university is located at coordinates $3^{\circ} 24^{\prime} 10.0^{\prime \prime} \mathrm{N}$ $76^{\circ} 32$ '53.0' $\mathrm{W}$. To perform this investigation, a concordance, observational, and cross-sectional study was performed. A total of 30 indoor spaces and six outdoor spaces located in three buildings, "Edificio Fundadores" (Founders Building, Block 1), "Edificio Trabajadores" (Workers Building, Block 3), and "Edificio Laboratorios" (Laboratory Building, Block 4) were evaluated.

Environmental sampling was performed quarterly for a period of 12 months (March 18, July 18, November 18, and March 19) using dichloran rose bengal chloramphenicol (Scharlau, Spain) agar as culture medium in $90-\mathrm{mm} \times 15-\mathrm{mm}$ Petri dishes. The quality control of the culture media was performed by leaving the boxes at room temperature for 5 days, during which time the absence of microbial growth was verified. A total of 120 samples were collected indoors (40 per building) and a total of 24 samples were collected outdoors (16 per building). Samples were collected between 9:00 am and 12:30 pm, with a minimum difference of 2-3 days among buildings. The indoor and outdoor sampling was performed using two techniques: 1) using an Air Ideal 3P air sampler (BioMérieux) that was configured to let through an air volume of $100 \mathrm{~L} / \mathrm{min}$ [34] which impacted the culture media for 1 min; and 2) using the gravimetric plate sedimentation method proposed by Omeliansky adjusted to a time of $20 \min [1,33,35,36]$.

Samples were simultaneously taken at the same sampling place $1 \mathrm{~m}$ above the ground. Samples were properly coded and transported to the laboratory using chlorinated polyethylene $(\mathrm{CPE})$ containers and incubated at room temperature $\left(25^{\circ} \mathrm{C} \pm 2^{\circ} \mathrm{C}\right)$ between 5 and 8 days with daily monitoring until the complete development of the colonies. The quantification of colony forming units of mold and yeast per cubic meter of air $\left(\mathrm{CFU} / \mathrm{m}^{3}\right)$ using the gravimetric method was performed by employing the formula proposed by Omeliansky $[33,35]$.

$$
N=5 a \times 10^{4}(b t)^{-1}
$$

...where $\mathrm{N}$ : $\mathrm{CFU} / \mathrm{m}^{3}$ of air; $a$ : number of colonies per Petri dish; $b$ : area of the Petri dish in $\mathrm{cm}^{2}$; and $t$ : exposure time in $\min$.

When using the volumetric method, CFUs were calculated using the correction table associated with the equipment. 


\section{Fungal Identification}

Fungal identification was performed by considering the macroscopic characteristics by analyzing the front and back of the fungal colonies with a stereo microscope (Motic brand, Ref. SMZ161 T LED). Microscopic observations were made by colony dissociation and adhesive tape technique [37] with lactophenol blue using two microscopes BH2 Double-Action Ball Head and HX 21 (Olympus). For fungal identification, the descriptions and keys employed by De Hoog [38], Piontelli [39], and Koneman [37] were used. To verify fungi identification, 500 strains, with an average of 120 strains per sample, were chosen at random, isolated, purified on Potato Dextrose Agar (Merck), and shipped to an external evaluator.

\section{Statistical Analysis}

For statistical analyses, assumptions were evaluated using parametric tests, such as the KolmogorovSmirnov normality test. To evaluate the differences between quantitative variables, the Mann-Whitney U test was performed when comparing two variables and the Kruskal-Wallis test for multiple comparisons. Data were descriptively treated from the graphs comparing differences in percentages of qualitative variables and determining the $95 \%$ confidence interval. InfoStat software version 2018 [40] was used to describe, compare, and graphically represent the variables. The significance level was set to $\alpha=0.05$. To compare the $\mathrm{CFU} / \mathrm{m}^{3}$ found in indoor environments, the values proposed by the WHO $\left(500 \mathrm{CFU} / \mathrm{m}^{3}\right)$ in 1990 were considered [41]. To determine the relative diversity of the genera, present in different environments, the Yadav and Madelin model of diversity was used [18].

\section{Results and Discussion}

In the study of indoor and outdoor environments of the three buildings at Universidad Santiago de Cali at four time points using the two proposed methodologies, a total of $64,497 \mathrm{CFU} / \mathrm{m}^{3}$ were counted, of which $34,930 \mathrm{CFU} / \mathrm{m}^{3}$ were isolated using the volumetric method and 29,567 $\mathrm{CFU} / \mathrm{m}^{3}$ using the gravimetric method. No significant statistical differences were observed when comparing the two methodologies $(P=0.0739$; Mann-Whitney $\mathrm{U}$ test). These results are consistent with the findings of Awad \& Mawla [33] who did not report significant differences among three sampling techniques, namely, impaction, filtration, and sedimentation.

When analyzing the values of fungal $\mathrm{CFU} / \mathrm{m}^{3}$ obtained from indoor and outdoor environments using the two sampling techniques, it was found that a total of $44,130 \mathrm{CFU} / \mathrm{m}^{3}$ were recorded in the internal environments: $26,210 \mathrm{CFU} / \mathrm{m}^{3}$ using the volumetric method and $17,920 \mathrm{CFU} / \mathrm{m}^{3}$ using the gravimetric method. Outdoor recordings showed a total of 20,367 $\mathrm{CFU} / \mathrm{m}^{3}: 8,720 \mathrm{CFU} / \mathrm{m}^{3}$ using the volumetric method and $11,647 \mathrm{CFU} / \mathrm{m}^{3}$ using the gravimetric method. Significant statistical differences were found between indoor and outdoor fungal load using the gravimetric method $(P=0.0002)$ but not with the volumetric method $(P=0.3156)$. When comparing the fungal load indoors, there was a statistical significance between the two methods used $(P=0.0035)$, with the fungal count being higher using the volumetric method. According to the fungal levels obtained with both methodologies, indoor values were lower than outdoor values, where a greater number of outliers were also found.

When comparing the fungal load of indoor and outdoor environments in each building using the different sampling techniques, we did not find significant statistical differences, except for Block 1, where differences were significant when comparing the indoor and outdoor environments using the gravimetric method $(P=0.0004)$ and indoors when comparing the two methodologies $(P=0.0005$, Fig. 1$)$.

When comparing the fungal loads of the indoor and outdoor environments in each building at four sampling times (Fig. 2), we did not find significant statistical differences between the two sampling methods. Specifically, only significant differences were found in indoor environments of the three buildings in the first sampling using the gravimetric method (March 2018; $P$ $=0.0079$; Kruskal-Wallis test). At other three sampling time points, there were no significant differences indoors or outdoors with either of the two methodologies. The highest fungal load was found in outdoor environments using both methods. The comparison of both methods revealed no significant statistical differences among the four sampling time points either indoors or outdoors. These results show that the gravimetric method using the Omeliansky formula is a good technique to measure the concentration of anemophilous fungi.

The concentration and variability of indoor fungal loads obtained using the two sampling techniques could be explained by the characteristics of indoor spaces. Indoor spaces are generally closed spaces with central or fixed air conditioning, closed windows, and certain environmental variations that may promote the permanence of conidia or fungal spores suspended in the air. Additionally, the architecture, construction materials, cleanliness, and human activity could influence the presence of fungi in these spaces [14, 42]. Temperature and relative humidity are considered key factors in the development of environmental fungi. Some researchers agree that the concentration of airborne spores increases with increase in temperature, relative humidity, and even wind speed [43-45]. However, it may take some time for these factors to affect fungal levels, resulting in uncertain data [46]. Indoor environments, such as those found in the buildings studied, have closed air conditioning systems that keep the area semi- 

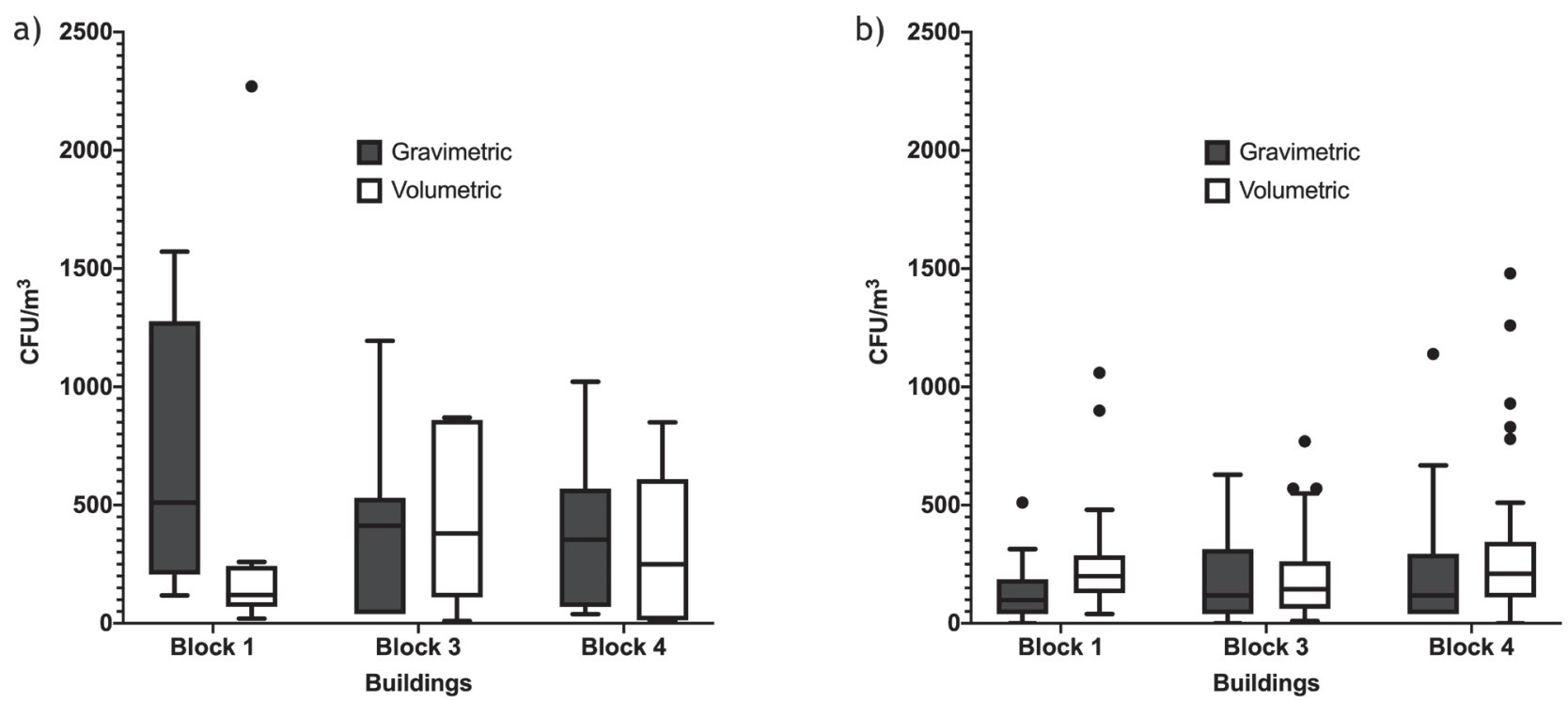

Fig. 1. Levels of CFU $/ \mathrm{m}^{3}$ values of three buildings of the Santiago de Cali University. a) Outdoor environments b) Indoor environments.

isolated from external environmental factors. This results in a microenvironment that can be altered by fungi transported inward from an outdoor environment through fomites or people entering or leaving these spaces. Consequently, a useful indicator of the patterns of fungal air densities that last over time was obtained, as indicated in Figs 1 and 2 [47].

\section{Genera Diversity According to the Yadav and Madelin Classification Criteria Based on Isolation Frequency}

To determine the relative abundance of fungi found in the indoor and outdoor environments using the two sampling methods, the Yadav and Madelin category classification system was used [18]. Considering the 28 genera found throughout the study, the greatest fungal diversity [24 genera $(85.71 \%)$ ] was obtained using the volumetric method, whereas 21 genera $(75.00 \%)$ where found with the gravimetric method. With both sampling methods, colonies of the genera Aspergillus, Penicillium, Cladosporium, Paecilomyces, Curvularia, Rhodotorula, Ustilago, Fusarium, Acremonium, Chrysonilia, Trichosporon, Arthrographium, and Nigrospora were obtained, in addition to unidentified yeasts or fungi, and sterile mycelia. The highest frequency of isolates corresponded to the genus Cladosporium, accounting for $82.17 \%$ of the organisms when using the volumetric method and $53.49 \%$ when using the gravimetric method, being the only fungus classified as "very common" [18]. The greatest fungal diversity was obtained using the volumetric method (Table 1).

The greatest diversity of fungal genera obtained using the volumetric method was found in Blocks 1 and 3 with 17 genera, followed by Block 4 with 13 genera. Using the gravimetric method, the greatest genera diversity was found in Block 4 with 17 genera, followed by Block 3 with 15 genera, and Block 1 with 13 genera. Aspergillus, Penicillium, Cladosporium, and Fusarium were the genera of fungus classified as "common,"
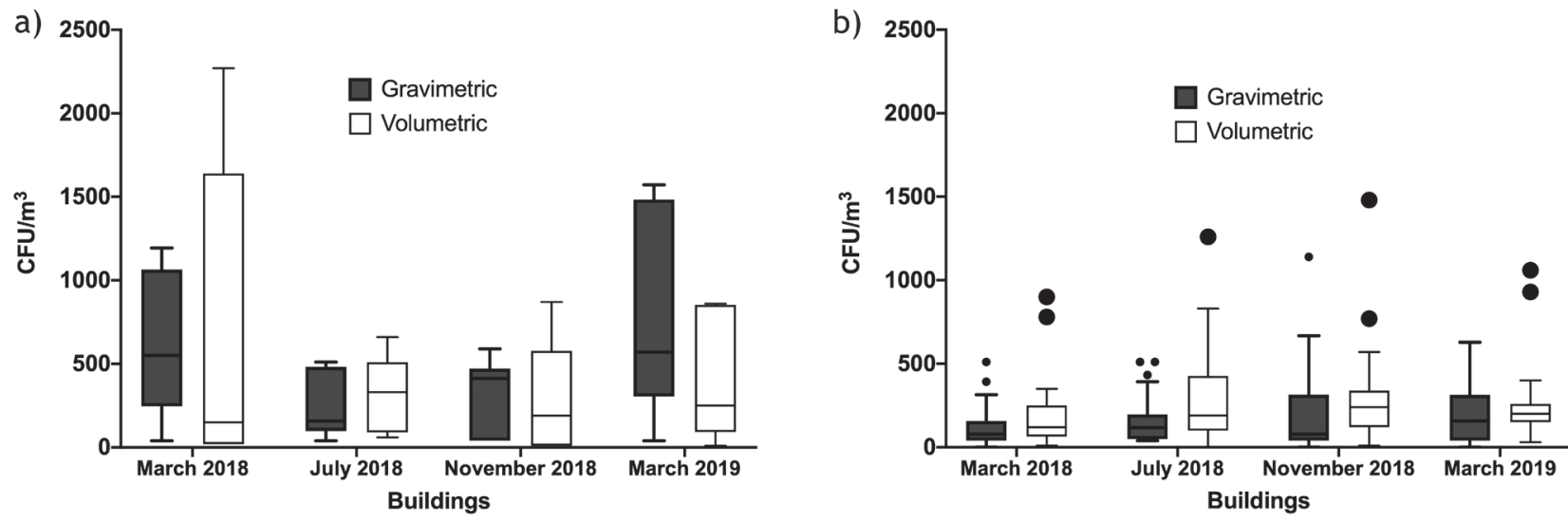

Fig. 2. Levels of CFU/m3 found in internal environments of three buildings of the Santiago de Cali University, in the four sampling times, compared to the fungal load of the respective external environments. a) Outdoor environments b) Indoor environments. 
Table 1. Classification according to Yadav and Madelin based on the frequency of isolates of genera of fungi with the two sampling methods.

\begin{tabular}{|c|c|c|}
\hline & $81-100 \%$ & Very common \\
\hline & $61-80 \%$ & Common \\
\hline & $41-60 \%$ & Frequent \\
\hline & $21-40 \%$ & Occasional \\
\hline & $0,1-20 \%$ & Rare \\
\hline
\end{tabular}

\begin{tabular}{|c|c|c|c|}
\hline \multirow{2}{*}{ Fungi } & \multicolumn{2}{|c|}{ Volumetric method } & $\begin{array}{l}\text { Gravimetric } \\
\text { method }\end{array}$ \\
\hline & $\mathrm{N}$ & $\%$ & $\%$ \\
\hline Cladosporium & 106 & 82,17 & 53,49 \\
\hline Mycelia sterilia & 88 & 68,22 & 54,26 \\
\hline Penicillium & 71 & 55,04 & 18,60 \\
\hline Aspergillus & 52 & 40,31 & 16,28 \\
\hline Yeast & 40 & 31,01 & 17,05 \\
\hline Fusarium & 31 & 24,03 & 10,08 \\
\hline Chrysonilia & 20 & 15,50 & 19,38 \\
\hline Paecilomyces & 20 & 15,50 & 5,43 \\
\hline Curvularia & 12 & 9,30 & 5,43 \\
\hline Trichoderma & 6 & 4,65 & 4,65 \\
\hline Rhodotorula & 5 & 3,88 & 3,10 \\
\hline Ustilago & 4 & 3,10 & 0,78 \\
\hline Acremonium & 4 & 3,10 & 2,33 \\
\hline Artrographium & 3 & 2,33 & 0,78 \\
\hline Eurotium & 2 & 1,55 & - \\
\hline Trichosporon & 1 & 0,78 & 0,78 \\
\hline Nigrospora & 1 & 0,78 & 2,33 \\
\hline Veronaea & 1 & 0,78 & - \\
\hline Phoma & 1 & 0,78 & - \\
\hline Alternaria & 1 & 0,78 & - \\
\hline Rhizopus & 1 & 0,78 & - \\
\hline Beauveria & 1 & 0,78 & - \\
\hline Chaetomium & 1 & 0,78 & - \\
\hline Mucor & - & - & 0,78 \\
\hline Neoscytalidium & - & - & 0,78 \\
\hline Cylindrocarpon & - & - & 0,78 \\
\hline Exophiala & - & - & 2,33 \\
\hline Unidentified & 1 & 0,78 & 3,10 \\
\hline
\end{tabular}

"frequent," and "occasional," excluding yeasts (without specific genera or species) and Chrysonilia (contaminating fungus, Table 2) [18].

When comparing the main fungi present in the indoor and outdoor environments of the three buildings using the two sampling techniques, a greater number of $\mathrm{CFU} / \mathrm{m}^{3}$ of the Cladosporium genus was found using the volumetric method $\left(11,530 \mathrm{CFU} / \mathrm{m}^{3} ; 43.99 \%\right)$, followed by Mycelia sterilia $\left(6,850 \mathrm{CFU} / \mathrm{m}^{3} ; 26.14 \%\right)$, Penicillium (2,370 CF/m³ ; 9.04\%), Fusarium (1,870 CFU/m³; 7.13\%), Aspergillus $\left(1,800 \mathrm{CFU} / \mathrm{m}^{3} ; 6.87 \%\right)$, and to a lesser extent, other mold genera $\left(900 \mathrm{CFU} / \mathrm{m}^{3} ; 3.48 \%\right)$ and yeasts $\left(890 \mathrm{CFU} / \mathrm{m}^{3} ; 3.35 \%\right)$. Using the gravimetric method, the genus Cladosporium $\left(5,187 \mathrm{CFU} / \mathrm{m}^{3}\right.$; 28.95\%) was first isolated, followed by Aspergillus (1,218 CFU/m³ ; 6.80\%), Fusarium (903 CFU/m³ ; 5.04\%), and Penicillium (825 CFU/m $\left.3 \mathrm{~m}^{3} ; 4.61 \%\right)$. Counts of hyaline and pigmented non-sporulated mycelia $\left(6,759 \mathrm{CFU} / \mathrm{m}^{3}\right.$; $37.72 \%)$, yeasts $(1,020 ; 5.70 \%)$, and other unidentified mold genera $(2,004 ; 11.18 \%)$ were also obtained.

When comparing the main genera of isolated fungi obtained outdoors and indoors using the two proposed methodologies (Fig. 3), we did not observe significant differences when evaluating the outdoor environments. However, when the indoor environments of the three buildings were evaluated, the genera Cladosporium, Penicillium, and Aspergillus were isolated more frequently using the volumetric method, and these differences were statistically significant $(P<0.0001)$. The genera Fusarium, Chrysonilia, yeasts other than Rhodotorula and M. sterilia did not show significant statistical differences.

The predominant genus in the indoor and outdoor environments was Cladosporium, being the volumetric method with the highest detection levels. This is mainly due to the dependence on air turbulence $[15,48]$. Several studies have reported that the genus Cladosporium is one of the most frequently found organism in the indoor and outdoor environments (up to 33\%) [45, 49-53]. The dimensions of the conidia, which are larger than those of the genera Aspergillus and Penicillium, favors their capture through different sampling methods [16]. Fusarium exhibited a behavior similar to that of Cladosporium with both sampling methods, suggesting that the size of the spores is extremely important to facilitate their capture as well as their density and aerodynamic shape.

Aspergillus and Penicillium were the two dominant genera, showing significant statistical differences in interior building spaces between the two methods. The fact that these differences were only found in indoor environments suggests that there are significant variations in the results obtained at different sampling points. However, it is difficult to determine why these differences occur indoors and not outdoors. Some researchers suggest that the air dynamics in these spaces as well as the aerodynamic shape of some fungal spores influence these results [16]. In general, the air in indoor environments is less dynamic, and the 
Table 2. Classification according to Yadav and Madelin based on the frequency of fungal isolations with the two sampling methods in each of the buildings studied.

\begin{tabular}{|c|c|c|}
\hline & $81-100 \%$ & Very common \\
\hline & $61-80 \%$ & Common \\
\hline $41-60 \%$ & Frequent \\
\hline & $21-40 \%$ & Occasional \\
\hline & $0,1-20 \%$ & Rare \\
\hline & \multicolumn{2}{|c|}{ Not found } \\
\hline
\end{tabular}

\begin{tabular}{|c|c|c|c|c|c|c|c|c|c|c|c|c|}
\hline \multirow{3}{*}{ Fungi } & \multicolumn{6}{|c|}{ Volumetric method } & \multicolumn{6}{|c|}{ Gravimetric method } \\
\hline & \multicolumn{2}{|c|}{ Block 1} & \multicolumn{2}{|c|}{ Block 3} & \multicolumn{2}{|c|}{ Block 4} & \multicolumn{2}{|c|}{ Block 1} & \multicolumn{2}{|c|}{ Block 3} & \multicolumn{2}{|c|}{ Block 4} \\
\hline & $\mathrm{N}$ & $\%$ & $\mathrm{~N}$ & $\%$ & $\mathrm{~N}$ & $\%$ & $\mathrm{~N}$ & $\%$ & $\mathrm{~N}$ & $\%$ & $\mathrm{~N}$ & $\%$ \\
\hline Cladosporium & 42 & 95,45 & 33 & 75,00 & 31 & 75,61 & 21 & 47,73 & 26 & 59,09 & 22 & 53,66 \\
\hline Mycelia sterilia & 32 & 72,73 & 31 & 70,45 & 25 & 60,98 & 22 & 50,00 & 25 & 56,82 & 23 & 56,10 \\
\hline Aspergillus & 21 & 47,73 & 15 & 34,09 & 16 & 39,02 & 11 & 25,00 & 4 & 9,09 & 3 & 7,32 \\
\hline Penicillium & 20 & 45,45 & 24 & 54,55 & 27 & 65,85 & 8 & 18,18 & 7 & 15,91 & 9 & 21,95 \\
\hline Fusarium & 15 & 34,09 & 8 & 18,18 & 8 & 19,51 & 9 & 20,45 & 3 & 6,82 & 1 & 2,44 \\
\hline Yeast & 15 & 34,09 & 13 & 29,55 & 12 & 29,27 & 6 & 13,64 & 9 & 20,45 & 7 & 17,07 \\
\hline Paecilomyces & 9 & 20,45 & 4 & 9,09 & 7 & 17,07 & 3 & 6,82 & 3 & 6,82 & 1 & 2,44 \\
\hline Curvularia & 8 & 18,18 & 1 & 2,27 & 3 & 7,32 & 3 & 6,82 & 4 & 9,09 & - & - \\
\hline Acremonium & 4 & 9,09 & - & - & - & - & - & - & 3 & 6,82 & - & - \\
\hline Chrysonilia & 4 & 9,09 & 9 & 20,45 & 7 & 17,07 & 6 & 13,64 & 9 & 20,45 & 10 & 24,39 \\
\hline Artrographium & 3 & 6,82 & - & - & - & - & - & - & - & - & 1 & 2,44 \\
\hline Trichoderma & 3 & 6,82 & 2 & 4,55 & 1 & 2,44 & 3 & 6,82 & - & - & 3 & 7,32 \\
\hline Ustilago & 2 & 4,55 & - & - & 2 & 4,88 & - & - & - & - & 1 & 2,44 \\
\hline Rhodotorula & 1 & 2,27 & 2 & 4,55 & 2 & 4,88 & 2 & 4,55 & 1 & 2,27 & 1 & 2,44 \\
\hline Veronaea & 1 & 2,27 & - & - & - & - & - & - & & - & - & - \\
\hline Trichosporon & 1 & 2,27 & - & - & - & - & - & - & 1 & 2,27 & - & - \\
\hline Phoma & - & - & - & - & 1 & 2,44 & - & - & & - & - & - \\
\hline Alternaria & - & - & 1 & 2,27 & - & - & - & - & & - & - & - \\
\hline Eurotium & - & - & 2 & 4,55 & - & - & - & - & & - & - & - \\
\hline Rhizopus & - & - & 1 & 2,27 & - & - & - & - & & - & - & - \\
\hline Beauveria & - & - & 1 & 2,27 & - & - & - & - & & - & - & - \\
\hline Chaetomium & - & - & 1 & 2,27 & - & - & - & - & & - & - & - \\
\hline Nigrospora & 1 & 2,27 & - & - & - & - & - & - & 1 & 2,27 & 2 & 4,88 \\
\hline Mucor & - & - & - & - & - & - & - & - & - & - & 1 & 2,44 \\
\hline Neoscytalidium & - & - & - & - & - & - & 1 & 2,27 & - & - & - & - \\
\hline Cylindrocarpon & - & - & - & - & - & - & - & - & & - & 1 & 2,44 \\
\hline Exophiala & - & - & - & - & - & - & - & - & 2 & 4,55 & 1 & 2,44 \\
\hline Unidentified & - & - & 1 & 2,27 & - & - & - & - & 1 & 2,27 & 3 & 7,32 \\
\hline & 87 & & 70 & & 70 & & 41 & & 44 & & 42 & \\
\hline
\end{tabular}



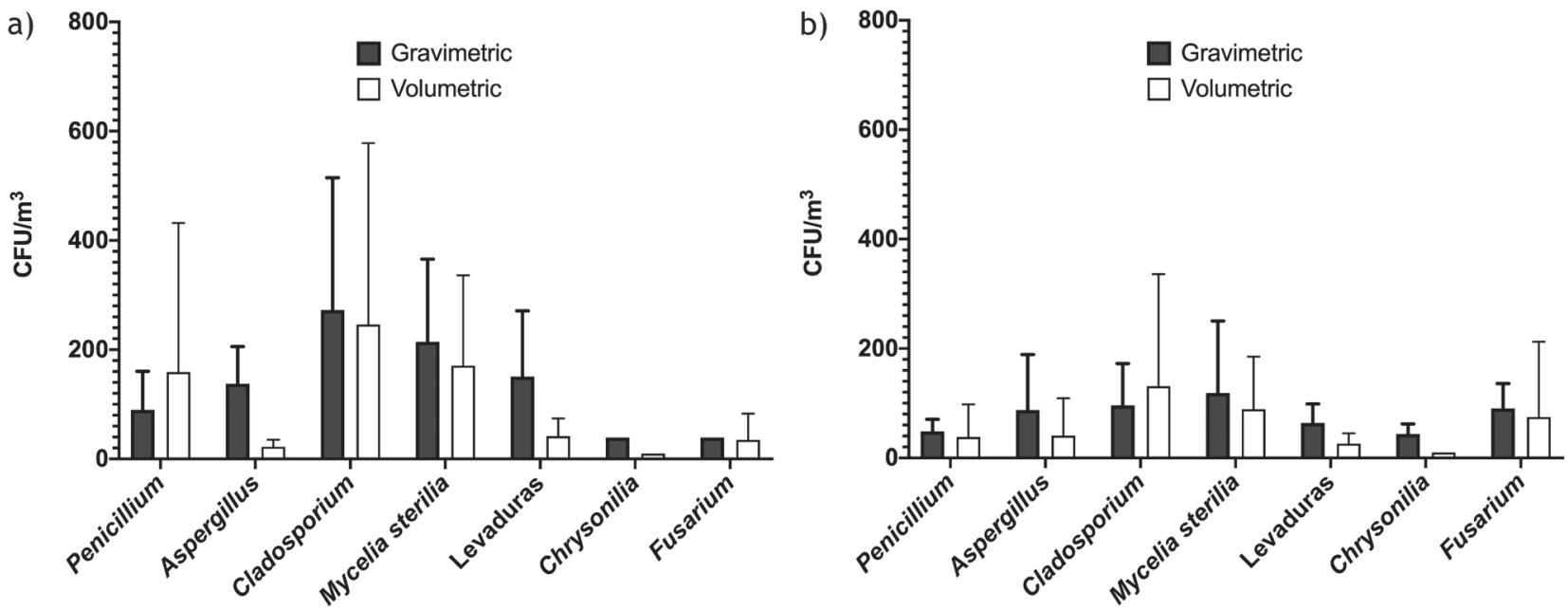

Fig. 3. The main genus of fungi found in indoor and outdoor environments with the different sampling methods. a) Outdoor environments b) Indoor environments.

volumetric method, which is an active method, has the ability to capture more spores owing to its air aspiration system. Taking into account that the gravimetric method depends on sedimentation and air turbulence as opposed to volumetric samplers, the absence of statistical significance in the outdoor environments may be due to the fact that the wind favors the dispersion of a greater number of mature spores and its subsequent contact with the culture medium, thereby allowing spores to reproduce $[44,45]$.

Although the gravimetric method obtained lower values for $\mathrm{CFU} / \mathrm{m}^{3}$ counts $[16,48]$ and variability of the isolated genera, it did not show, in general, significant statistical differences compared with the volumetric method. This suggests that the dynamics that characterize the different sampling methods are affected not only by environmental factors and the space studied but also by the limitations of each method [49]. When comparing the main genera of fungi isolated using the two sampling methods and some of the identified morphospecies (Table 3), it was evident that the most representative genera and morphospecies were similar. These genera are also frequently isolated by other researchers [54]. Similarly, it was possible to demonstrate that high fungal levels in outdoor environments tend to increase fungal levels in indoor environments [22].

Chrysonilia spp. is a highly contaminating mold and generally, the Petri dishes that present it must be discarded. It interferes with the correct count and isolation of the accompanying colonies [54]. However, it is a genus that is frequently sampled in environments with air conditioning systems, which favor its permanence and distribution in the environment. This genus was detected in samples from the three buildings, appearing more frequently when using the gravimetric method, and to a lesser extent, when using the volumetric method. This could be explained by the shorter sampling time used with the later method and the probability that this fungal genus will be better captured by the gravimetric method. Another difference observed in this study was the isolation of a greater number of yeasts with the gravimetric method. Yeasts do not release spores in the same manner as filamentous fungi; many of them are released from the microbiota, primarily from mucosa and skin of humans and animals. They can be found forming conglomerates, which could explain why they do not remain floating in the environments for long periods of time, rather settle on surfaces [7].

Many of the fungi that remain in the environment cause infections. Among these are some species of Cladosporium, Aspergillus, Fusarium, Rhizopus, and Mucor. However, they do not usually cause complications in individuals with a healthy immune system. Immunocompromised individuals, such as those undergoing chemotherapy or organ transplantation, suffering from leukemias, or diagnosed with HIV, often suffer from infections mediated by these microorganisms, which have the potential to cause serious and fatal diseases [55-57]. In a clinical context, a patient on a hospital bed could acquire a nosocomial infection by fungi or other microorganisms. In this case, an immobile body with a wound or burn totally or partially exposed for a period of time would simulate a culture medium in which the fungal particles are deposited in a manner similar to what happens in the gravimetric method used for the capture of fungal spores. This method would be suited for environmental sampling in such cases because it would simulate the natural mechanism of passive deposition of spores [57-59].

According to previous studies based on passive gravimetric sedimentation methods using the Omeliansky formula, the variations observed with this technique are usually owing to the diversity in 
Table 3. Morphospecies isolated with the gravimetric and the volumetric method.

\begin{tabular}{|c|c|}
\hline Volumetric method & Gravimetric method \\
\hline Alternaria alternata & Aspergillus section Aspergillus (A. glaucus) \\
\hline Aspergillus section Aspergillus (A. glaucus) & Aspergillus section Circumdati (A. ochraceus) \\
\hline Aspergillus section Aspergillus (A. hollandicus) & Aspergillus section Cremei (A. inflatum) \\
\hline Aspergillus section Circumdati (A. ochraceus) & Aspergillus section Cremei (A. wentii) \\
\hline Aspergillus section Cremei (A. inflatum) & Aspergillus section Flavi (A. flavus) \\
\hline Aspergillus section Cremei (A. wentii) & Aspergillus section Flavi (A. tamarii) \\
\hline Aspergillus section Flavi (A. flavus) & Aspergillus section Fumigati (A. fumigatus) \\
\hline Aspergillus section Flavi (A. tamarii) & Aspergillus section Nidulantes (A. nidulans) \\
\hline Aspergillus section Flavipedes (A. flavipens) & Aspergillus section Nigri (A. niger) \\
\hline Aspergillus section Fumigati (A. fumigatus) & Aspergillus Section Restricti (A. restrictus) \\
\hline Aspergillus section Nidulantes (A. nidulans) & Aspergillus section Terrei (A. terreus) \\
\hline Aspergillus section Nigri (A. niger) & Aspergillus section Versicolores (A. versicolor) \\
\hline Aspergillus section Terrei (A. terreus) & Cladosporium herbarum Species Complex \\
\hline Aspergillus section Versicolores (A. versicolor) & $\begin{array}{l}\text { Cladosporium macrocarpum (Cladosporium herbarum Species } \\
\text { Complex) }\end{array}$ \\
\hline Cladosporium herbarum Species Complex & Cladosporium sphaerospermum Species Complex \\
\hline $\begin{array}{l}\text { Cladosporium macrocarpum (Cladosporium herbarum Species } \\
\text { Complex) }\end{array}$ & Curvularia geniculata \\
\hline Cladosporium sphaerospermum Species Complex & Curvularia lunata \\
\hline Curvularia geniculata & Fusarium oxysporum Species Complex (FOSC) \\
\hline Curvularia lunata & Fusarium solani Species Complex (FSSC) \\
\hline Fusarium oxysporum Species Complex (FOSC) & Mucor circinelloides \\
\hline Fusarium solani Species Complex (FSSC) & Paecilomyces variotii \\
\hline Paecilomyces variotii & Penicillium chrysogenum \\
\hline Penicillium chrysogenum & Penicillium frequentans \\
\hline Penicillium frequentans & Penicillium funiculosum (Talaromyces foniculosus) \\
\hline Penicillium funiculosum (Talaromyces foniculosus) & Penicillium purpurogenum (Talaromyces purpurogenum) \\
\hline Penicillium purpurogenum (Talaromyces purpurogenum) & Trichoderma harzianum \\
\hline \multicolumn{2}{|l|}{ Rhizopus stolonifer } \\
\hline Trichoderma harzianum & \\
\hline
\end{tabular}

sampling times, culture media, and sampling height used [18, 20, 60], which also affect the volumetric method. Furthermore, in some cases, movements with the sampling equipment may influence the results. There are still no criteria to know how, when, or under what circumstances environmental sampling should be performed, either indoors or outdoors, or which organisms should be the target organisms of the study. Therefore, it is not possible to compare adequately the results obtained by different authors. However, the various sampling methods serve to estimate the degree of fungal contamination in a given area over a period of time.

\section{Conclusions}

This study showed the concentration and variability of viable and cultivable environmental fungi using two different methodologies employing volumetric and gravimetric concepts. Our data demonstrate that the volumetric technique, despite capturing a higher fungal load, can be compared with the gravimetric or sedimentation technique using the Omeliansky formula under similar conditions. Consequently, this method enables satisfactory determination of air contamination levels and variability of the species present at a certain site. 
Additionally, we determined that the two sampling methods used in this study captured in a similar manner the predominant genera outdoors and indoors of three buildings at Universidad Santiago de Cali, between March 2018 and March 2019; the captured genera included Cladosporium, Penicillium, Aspergillus, and Fusarium, with Cladosporium being the most frequently isolated genus.

\section{Acknowledgements}

We thank Universidad Santiago de Cali for funding the research project (521-621116-D65) and Article Processing Charge (APC).

We/The authors thank Crimson Interactive Pvt. Ltd. (Enago) for their assistance in manuscript translation and editing.

\section{Conflict of Interest}

The authors declare no conflict of interest.

\section{References}

1. HAYLEEYESUS S.F., MANAYE A.M. Microbiological Quality of Indoor Air in University Libraries. Asian Pac J Trop Biomed 4, S312, 2014.

2. DE LA ROSA M.C., MOSSO M.A., ULLÁN C. Air: habitat and transmission of microorganisms. Observat Medioamb 5, 375, 2002.

3. KASPRZYK I. Aeromycology - Main research fields of interest during the last 25 years. Ann Agric Environ Med AAEM 15, 1, 2008.

4. GEBAROWSKA E., PUSZ W., KUCIŃSKA J., KITA W. Comparative analysis of airborne bacteria and fungi in two salt mines in Poland. Aerobiologia 34, 127, 2018.

5. UMANA S., EDET N., UKO M., AGBO B., BASSEY M. Microbiological Quality of Indoor and Outdoor Air Within Biological Sciences Laboratories in Akwa Ibom State University, Nigeria. FEM 4, 124, 2018.

6. UMBAL C., JOSHI S.K., TRIVEDI U.K., GAUTAM S. Evaluating the colonization and distribution of fungal and bacterial bio-aerosol in Rajkot, western India using multiproxy approach. Air Qual Atmos Health 12, 693, 2019.

7. WEBSTER J., WEBER, R. Introduction to Fungi. $3^{\text {rd }}$ Edition. Cambridge. Cambridge University Press, 2007.

8. BERRUETA T.Y., OLIVARES L. Universidad Nacional Autónoma de México: Generalities of Mycology. Departamento de Microbiología y Parasitología. Facultad de Medicina. CDMX, México, 2017. Disponible en: http:// www.facmed.unam.mx/deptos/microbiologia/micologia/ generalidades.html [consultado el 10 de octubre de 2019].

9. CHAKRABORTY P., GHOSAL K., SENGUPTA K., KARAK P., SARKAR E. Airborne fungal spores in a suburban area of eastern India with reference to their allergenic potential and effect on asthma-related hospitalization. Palynology 54, 57, 2018.

10. DE-WEI L.I., KENDRICK B. Functional relationships between airborne fungal spores and enviromental factors in Kitchener-Waterloo, Ontario, as detected by Canonical correspondence análisis, Grana 33, 166, 1994.

11. WEBER R. Meteorologic variables in aerobiology. Immunol Allergy clin North Am 23, 22, 2003.

12. JONES A.M., HARRISON R.M. The Effects of Meteorological Factors on Atmospheric Bioaerosol Concentrations - a Review. Sci Total Environ 326, 80, 2004.

13. YAFETTO L., ADATOR EH. Fungal contaminations of indoor and outdoor air of buildings of the University of Cape Coast, Ghana. Studies in Fungi 3, 333, 2018.

14. ROSHAN S.K., GODINI H., NIKMANESH B., BAKHSHI H., CHARSIZADEH A. Study on the relationship between the concentration and type of fungal bio-aerosols at indoor and outdoor air in the Children's Medical Center, Tehran, Iran. Environ Monit Assess 191 (48), 1, 2019.

15. NJOKUOCHA R.C., OSAYI E.E., IKEGBUNAM C.N. Diversity of airborne mycofloral abundance and allergenic fungal spores of Enugu North, Nigeria. Aerobiologia 35, $1,2018$.

16. ROJAS T., MARTÍNEZ E., AIRA M.J. ALMAGUER M. Air mycobiota from internal environments: comparison of sampling methods. Boletín Micológico 23, 67, 2008.

17. RINCÓN M., MACIAS M. Study of environmental fungy in Bucaramanga city. Rev Univ Ind Santander 6, 37, 1969.

18. VILLAFAÑE F.L., CASTRO O.R., OLIER-CASTILLO D., PINILLA P.M. Determinación de la carga fúngica anemófila en seis sectores de la ciudad de Cartagena de Indias. CSV 1 (1), 15, 2009.

19. HERRERA A.B., RODRIGUEZ L., NIEDERBACHER J. Indoor biological contamination and its relationship with respiratory symptoms indicative of bronchial asthma in preschool children from Bucaramanga, Colombia. Biomedica 31, 357, 2011.

20. TOLOZA-MORENO D.L., LIZARAZO-FORERO L.M., BLANCO-BALBUENA J.O. Microbial Concentration and Composition in the Environment of the Jorge Palacios Preciado Central Library at Universidad Tecnológica y Pedagógica de Colombia, Tunja, Colombia. Tunja, Colombia. Actual. Biol 34 (97), 241, 2012.

21. VELANDIA D.H., VALIENTE E.L., LIZARAZO L.M. Caracterización Fúngica en el Archivo Histórico de la Universidad Pedagógica y Tecnológica de Colombia. Cienc en Desarro 4 (1), 115, 2013.

22. CAICEDO BEJARANO L.D. Study of the environmental mycobiota of three buildings at Universidad del Valle, Colombia, and its relationship with the symptoms of respiratory allergies that workers present, MSc Thesis, Repositorio Institucional UNNE. 2015. https://repositorio. unne.edu.ar/handle/123456789/468

23. DAZA-PEREZ A., MARTINEZ D., CARO-HERNANDEZ P.A. Sick Building Syndrome and Microbiological Quality of the Air in a University in the Colombian Southwest. ASMI 1, 7, 2018.

24. ALVAREZ R., REYES M.A., MADRIÑÁN C.D. Survey on environmental fungi in the city of Cali. Antioquia Méd $\mathbf{1 5}, \mathbf{4 9 7 ,} \mathbf{1 9 6 5}$.

25. GIRALDO-CASTRILLÓN M., TORRES-GONZÁLES C., DÍAZ-ORTIZ J. Isolation of cellulolytic fungi that cause biodegradation of the Central Library at Universidad del Valle (Cali-Colombia). Rev Mex Mic 29, 9, 2009.

26. KENGNE G.L., NYEGUE M.A., DJUIDJE C.A., GONSU K., ETOA F.X. Assessment of Indoor Microbial Quality of Library's Premise: Case of Central Library of the University of Yaoundé I. Open J Prev Med 8, 109, 2018. 
27. AHMED F., HOSSAIN S., HOSSAIN S., FAKHRUDDIN A.N.M., ABDULLAH A.T.M., CHOWDHURY M.A.Z., GAN S.H. Impact of household air pollution on human health: source identification and systematic management approach. SN Appl Sci 1, 418, 2019.

28. RÍOS J.M. Aeromycology and its importance for medicine. Rev Méd Cient 24 (2), 28, 2011.

29. OECD. OECD Environmental Outlook to 2050: The Consequences of Inaction. OECD Publishing, Paris. All Outlook information available on: www.oecd.org/ environment/outlookto2050

30. WHO. Evolution of WHO air quality guidelines: past, present and future. Copenhagen: WHO Regional Office for Europe, 2017.

31. MAYORGA J. P. The air that I Breathe. The state of the air quality. GREENPEACE 2018 México A. C, 2018.

32. KAMPAN S. Air Quality and Employee Hygiene-related Behavior in a Post Anesthesia Care Unit in Thailand. Open Nurs J 13, 100, 2019.

33. AWAD A., MAWLA H. Sedimentation with the Omeliansky Formula as an Accepted Technique for Quantifying Airborne Fungi. Pol J Environ Stud 21 (6) 1539, 2012

34. BOTTALE A.J., RIERA L.M.C. Establishment of internal microbiological limits for areas classified as level D. Rev Cubana Farm 50, 30, 2016.

35. OMELIANSKY V.L. Manual in Microbiology. USSR academy of sciences, Moscow, Leningrad, 1940.

36. BOGOMOLOVA E., KIRTSIDELI I. Airborne fungi in four stations of the St. Petersburg Underground railway system. Int Biodeter Biodegr 63, 156, 2009.

37. KONEMAN E.W., ROBERTS G.D. Practical laboratory mycology. Ed. 3 Baltimore. MD.USA. 211pp. 1985.

38. HOOG G.S. DE. HOOG G.S. DE., GUARRO J., GENÉ, J., FIGUERAS M. J. "Atlas of Clinical Fungi". CBS, Utrecht, 2000.

39. PIONTELLI, E. Manual of common filamentous microfungi I. Alba Producciones. Chile. Valparaiso. 2013.

40. BALZARINI M., GONZALEZ L., TABLADA M., CASANOVES F., DI RIENZO J., ROBLEDO C. Infostat Manual del Usuario. Manual del Usuario”, Ed. Brujas, Córdoba, Argentina, 2020.

41. ILIĆ P., BOŽIĆ J., ILIĆ S. Microbiological Air Contamination in Hospital. IJPSAT 7, 183, 2018.

42. GOPALAKRISHNAN S., DEVASSIKUTTY A., MATHEW M., AYYAPPAN D., THIAGARAJAN S., RAGHUNATHAN R. Passive Release of Fungal Spores from Synthetic Solid Waste Surfaces. Aerosol Air Qual Res 16, 1441, 2016.

43. GOPALAKRISHNAN S., ARIGELA R., GUPTA. SK. RAGHUNATHAN R. Dynamic response of passive release of fungal spores from exposure to air. J Aerosol Sci 133, 37, 2019.

44. ELENJIKAMALIL. S.M.R., KELKAR-MANE V. Seasonal variations in the aerobiological parameters of a state archival repository in India. World J Pharm Res 8, 1459, 2019.

45. PACE L., BOCCACCI L., CASILLI M., FATTORINI S. Temporal variations in the diversity of airborne fungal spores in a Mediterranean high altitude site. Atmos Environ 210, 166, 2019.
46. CRANDALL S., GILBERT G. Meteorological factors associated with abundance of airborne fungal spores over natural vegetation. Atmos Environ 162, 87, 2017.

47. BORREGO S.F., MOLINA A. Determination of Viable Allergenic Fungi in the Documents Repository Environment of the National Archive of Cuba. Austin J Public Health Epidemiol 5 (3), 1077, 2018.

48. EMYGDIO A.P., DEGOBBI C., GONCALVES F., ANDRADE M. One Year of Temporal Characterization of Fungal Spore Concentration in São Paulo Metropolitan Area, Brazil. J Aerosol Sci 115, 121, 2018.

49. RAMOS R., MEZA V. Effects of some meteorological factors on the concentration of fungal spores at Plaza San Martín de Lima. Ecol Apl 16 (2), 143, 2017.

50. SARDA R., BAISNÉE D., GUINOT B., SODEAU J., O'CONNOR D., BELMONTE J., BESANCENOT J.P., PETIT J.E., THIBAUDON M., OLIVER G., SINDT C., GROS V. Variability and Geographical Origin of Five Years Airborne Fungal Spore Concentrations Measured at Saclay, France from 2014 to 2018. Remote Sens 11, 1, 2019.

51. ROY S., CHAKRABORTY A., MAITRA S., KASHINATH B. Monitoring of airborne fungal spore load in relation to meteorological factors, air pollutants and allergic symptoms in Farakka, an unexplored biozone of eastern India. Environ Monit Assess 189, 1, 2017.

52. ŠČEVKOVÁ J., KOVÁČ J. First fungal spore calendar for the atmosphere of Bratislava, Slovakia. Aerobiologia 35, 343, 2019.

53. SÁNCHEZ ESPINOSA K.C., ALMAGUER CHAVES M., PÉREZ RAMIREZ I., ROJAS FLORES T.I., AIRA RODRÍGUEZ M.J. Fungal diversity in the atmosphere of Havana (CUBA) during three dry periods. Rev Int Contam Ambient 35, 137, 2019.

54. WORLD HEALTH ORGANIZATION (WHO).Who Issues Organic Chemical Report. Indoor Air Quality Uptade. 3 (1), 9, 1990.

55. HALEEM KHAN AA., MOHAN KARUPPAYIL S. Fungal pollution of indoor environments and its management. Saudi J Biol Sci 19, 405, 2012.

56. ZIAEE A., ZIA M., GOLI M. Identification of saprophytic and allergenic fungi in indoor and outdoor environments. Environ Monit Assess 190, 574, 2018.

57. OTALORA VALDERRAMA S., HERRERO MARTÍNEZ J.A., HERNANDEZ TORRES AB., MORAL ESCUDERO E., GÓMEZ J., SEGOVIA HERNÁNDEZ M. Systemic mycoses in immunocompromised patients. Medicine Programa de Formación Médica Continuada Acreditado 12, 3357, 2018.

58. SHIELDS B., ROSENBACH M., BROWN Z., BERGER A., FORD B., WANAT K. Angioinvasive Fungal Infections Impacting the Skin: Background, Epidemiology, and Clinical Presentation (Part 1). J Am Acad Dermatol 80 (4), 869, 2018.

59. UPADHYAY V., KUMAR A., SINGH A., PANDEY J. Epidemiological characterization of dermatophytes at a tertiary care hospital in Eastern Uttar Pradesh, India. Curr Med Mycol 5, 1, 2019.

60. BORREGO S.F, PATRICIA G., GÓMEZ DE SARAVIA S., BATISTINI P., GARCIA M., LAVIN P., PERDOMO I. The quality of air at archives and the biodeterioration of photographs. Int Biodeterior Biodegrad 64, 139, 2010. 